\title{
BAGWORM (Lepidoptera: Psychidae) INFESTATION IN THE CENTENNIAL OF THE MALAYSIAN OIL PALM INDUSTRY - A REVIEW OF CAUSES AND CONTROL
}

\author{
BRIAN J WOOD* and NORMAN KAMARUDIN**
}

\begin{abstract}
In the sixties, the cause of outbreaks for leaf-eating caterpillars, particularly bagworms (Metisa plana and Pteroma pendula) and nettle caterpillars was shown to be applications of synthetic organochlorine insecticides. These disrupted the prevailing strong natural balance between the pests and their insect natural enemies, parasitoids and predators. These disruptive insecticides have long lasting contact residues and are lethal to the free flying natural enemies. Halting application of these pesticides caused many outbreaks to terminate quickly. Selective pesticides which were then brought in, killed the pests and relatively spared the enemies (integrated control). Such pesticides, in the form of lead arsenate (stomach acting), and trichlorfon (fast fading residues) were used in large scale application to suppress continuing infestation. Trunk injection (TI) which was later developed uses a suitable systemic organophosphate insecticide which is injected into palm trunks and kills only insects that eat the leaves. From the mid-sixties, outbreak became less common, but started to increase again in frequency and severity in the nineties. Formulations from Bacillus thuringiensis (Bt), and synthetic pyrethroid, such as cypermethrin and deltamethrin, were added to the range for regular use. Clean weeding could possibly reduce the survival of adult parasitoids by removing their shelter and floral food source. In parallel, oil palms in Sumatra had severe outbreaks of leaf-eating caterpillars in the 1950s and 1960s, associated with DDT dusting. When DDT was replaced by trichlorfon, parasitoid numbers increased and pest infestations became insignificant by the late sixties. In the nineties, fogging of synthetic pyrethroids caused new pest outbreaks, which more recently saw reduction in pest problems when control measures were restricted to selective applications. Despite awareness of the risks, 'minor build up' or 'infestation in the locality' may encourage 'precautionary' treatment. Disruptive application may be against other pests, and often outbreak can be traced back to this. A good example is Oryctes where synthetic pyrethroids are often applied in full cover sprays, and leaf-eater infestation commonly follows. In fact, there are very effective procedures to avoid significant Oryctes damage in young palm plantings without risky applications. There is an indication that some sectors are moving towards a cycle of outbreak, chemical knockdown, and re-outbreak. An investigation is suggested to put a significant area of palms onto a programme of entirely selective measures. Application would be based on action thresholds, but of equal importance is 'no application if they are not reached'. The ultimate aim is effective and sustainable regulation of the population size of bagworms and other pests.
\end{abstract}

Keywords: bagworms, nettle caterpillars, pest outbreak, disruptive pesticides, selective pesticides, Integrated Pest Management insect natural enemies, sustainability.

Date received: 20 March 2019; Sent for revision: 27 March 2019; Received in final form: 4 June 2019; Accepted: 12 July 2019.

* Merrivale, Exton Lane, Exton, Exeter, EX3 0PP, United Kingdom.

** Malaysian Palm Oil Board, 6 Persiaran Institusi, Bandar Baru Bangi, 43000 Kajang, Selangor, Malaysia.

E-mail: norman@mpob.gov.my

\section{INTRODUCTION}

Oil palm plantings in Malaysia and nearby territories have been subject to attack by leaf-eating caterpillars, 
primarily bagworms (Psychidae) and nettle caterpillars (Limacodidae $=$ Cochlidiidae), from the late 1950s. Bagworms have been particularly serious in the Malaysian peninsula, and in recent decades, outbreaks have been common. Generally, the leafeaters exist in low numbers, difficult to find except occasionally by intensive searching. Investigations in the early outbreaks showed that this scarcity was due to the control exercised by their insect natural enemies, the parasitoids (parasites that kill hosts, and have a free living stage) and predators. It was clear that the outbreaks resulted from an upset of this balance by applications of certain insecticides that killed the enemies more effectively than they did the pests, thus releasing those pests from the natural restraint. Pest populations, with their full increase potential realised, often reached numbers that substantially destroyed leaf over extensive areas, with a tendency to recur.

A dilemma has continued between measures to control attack and those which might cause increase in pest numbers. Our aim is to give an account of the history of bagworm occurrence in these territories, exploring the relationship to control measures. We touch on the occurrence of nettle caterpillars where the ecological principles are much the same, and on developments in Sumatra, where conditions and the history of oil palm pest incidence, have clear similarities to those in the Malaysian territories.

We use the terms pest 'incidence' and 'outbreak' to define populations of concern. Such definitions inevitably are subjective and on a range. 'Incidence' implies a population of a particular leaf-eater that is readily noticeable in the palm areas, but not at the stage of heavy damage. In an 'outbreak', one or more species has increased over an area of palms to the point where significant and obvious damage is visible. Of course there are subtleties - pest numbers may be increasing or decreasing naturally, so that the level of bagworm threat is not always clear in the literature, but reasonable assumptions can generally be made in context.

Malaysian territories have adjusted their names in accordance with political process in the period covered. Until 1963 the peninsula was Malaya, subsequently Peninsular Malaysia, which with the two states in the north of the island of Borneo, North Borneo (later Sabah) and Sarawak, became Malaysia. For continuity, here we use 'Peninsula', 'Sabah' and 'Sarawak' throughout.

\section{Bagworm Species in Oil Palms}

Three psychid species have commonly reached outbreak status, Metisa plana, Pteroma (Cremastopsyche) pendula, and Mahasena corbetti (Wood, 1968; Basri et al., 1988; Hoong and Ho, 1992). These were authenticated taxonomically by Norman et al. (1994). Various other species have been recorded, including Dapula (Clania) tertia, Amatissa cuprea, Brachcyttarus griseus, Oiketicoides sp., Cryptothelia cardiophaga, Manatha albipes and other species of these genera (Wood, 1968; Sankaran, 1970; Syed and Shah, 1977; Siti Ramlah et al., 2005). The only report known to us of any of them reaching outbreak status is D. tertia in Sumatra (see below Parallel Developments in Sumatra - Post 1990).

\section{PENINSULA MALAYSIA}

\section{Early Plantings to Late 1950s}

Oil palms were established in commercial plantations from 1917 (Corley and Tinker, 2016). Oil palm planted areas expanded rapidly to more than 50000 ha in this period. We are not aware of any reports of damaging incidence of bagworms, or any other leaf-eating caterpillars in this period. $P$. pendula and M. corbetti, known from coconuts, were found on the palm sometimes, but at low numbers (Corbett, 1927; Gater, 1925).

\section{Late 1950s to Mid 1960s}

Serious outbreaks of M. plana (not previously recorded on the palm) and $P$. pendula began to occur in the late 1950s. Control was attempted with mainly chlorinated hydrocarbon insecticides, related to DDT, such as endrin and dieldrin (no longer available, of course). Detailed investigation began from 1962. This concluded that the outbreaks largely followed these applications, and continued to recur as applications were repeated. That, together with experiences in other crops on a world basis, indicated that usually these leaf-eating caterpillars are kept at low numbers by insect natural enemies (Wood, 1968; 1971a). The basis is that the constancy of tropical perennial crop environmental conditions allows a continuous dynamic balance between leafeating pests (the hosts) and their natural enemies. The hosts increase, giving opportunity for the enemies to increase, so the hosts decrease, and so on. The leaf-eating pests have a huge increase potential (egg-laying capacity) all the time, but this is restrained by the natural enemies. Pesticides, by differentially killing the natural enemies, can allow this potential to be realised.

In evidence, in areas where there had been no such applications, all these species could be found but mostly only at low numbers by intensive searching. The outbreaks only occurred where the 'new' insecticides had been introduced (Wood, 1964). Further, an experimental deliberate upset trial showed an increase in M. plana. In this, a small patch of palms with a low infestation was treated by application of endrin and showed that the bagworm built up from there and slowly spread outwards (Wood, 1971a; 1973). 


\section{Protection Ecology Shown by These Experiences}

Restoration of natural balance. A main recommendation was to stop applications, and incidence generally declined, although with some later recurrence in some cases (Wood, 1971b). A key reason for recurrence is that the pesticides, in addition to killing the natural enemies, also disrupted the life cycle interaction between them and their hosts, the pests (Wood, 1971a). In the conditions that remain continually suitable to their activity, there is no evolutionary pressure for parasitoids, the key natural enemies, to adapt their life cycle timing to that of their hosts. All stages of both are present all the time, so an emerging adult parasitoid has an equal chance of finding a host at any time. This can be called Continuous Generation Mode (CGM). Pesticide-induced disruption tends to act differentially on different stages of the pest, and one stage becomes predominant. Thus, in outbreaks generally, pests are in Discrete Generation Mode (DGM), that is they are nearly all at the same age. This evidently is the case with bagworm and nettle caterpillar outbreaks in oil palms (Wood, 1971a; 1987) and also, illustrating the point, with the leaf mining beetle Coelaenomenodera lameensis (previously misidentified as C. elaeidis) (Hispidae) in Africa (Mariau, 1976; Corley and Tinker, 2016).

It follows that existence of DGM itself is indicative of upset balance. Throughout the following account of history, there is emphasis on timing of any control application to when maximum emergence of the eggs of that peak generation is just completed. After an outbreak a bagworm may seem to be dormant for some generations, but with individuals laying hundreds or thousands of eggs (depending on species), it can 'flare up' severely again, from a not very conspicuous base. Further, after an outbreak, numbers are likely to remain well above the usual balanced population for some time, even though not particularly noticeable.

Selective treatments. At the time of these developments in oil palms, the concept of selective control was developing in crop protection science. This arose from pesticides that could supplement applied biological control such as mass release of insectary-reared natural enemies (Stern et al., 1959). The concept was extending to pesticides that could help to restore balance by sparing enemies, parasitoids in particular, that are naturally present without rearing and release (Bartlett, 1964). Such selective materials evidently could help where there was subsequent flare up after stopping spray applications (Wood, 1963). Essentially, selective pesticides, contrary to disruptive ones, kill the pests more effectively than they kill key natural enemies.

Continuing investigation (Wood, 1968; Basri et al., 1995; Norman and Othman, 2016) showed that the main natural control of M. plana and P. pendula is from the wasp (Hymenoptera) parasitoids. The chlorinated hydrocarbons were much more lethal to them than to the leaf-eaters. Potentially disruptive insecticides in general have a broad spectrum (kill insects in a wide range of families), have long lasting residues (leave deposits that remain lethal for some time, specifically killing natural enemies as they return), and kill on contact (kill insects they touch rather than only those that feed on them) - often summarised as Broad Spectrum, Long Residual, Contact or BSLRC (Wood, 2002). They are mainly from the synthetic insecticides developed and introduced into agriculture since the 1940s.

Selective pesticides on the other hand, kill the pests more thoroughly than they kill the natural enemies. They lack one of the characters of the disruptive materials - they may have a narrower spectrum (more lethal to the pest groups than they are to the natural enemies), short contact residues (enemies less thoroughly eliminated, or can return quickly), and/or be stomach acting (only kill insects that eat the leaves). This is considered further below - Pesticides in Outbreaks - Cause or Cure?

Application of selective pesticides in the outbreaks of the early 1960s. The range of pesticides then available in the region was not great, but in trials, a stomach poison, lead arsenate, was found to give a good kill, and was applied, including by air. It showed the capability to eliminate infestation without further resurgence (Wood, 1968). It was used in a few cases including aerially, with precaution against possible toxicity to operators, and the large quantity per hectare needed in application. Among 'newer' pesticides, trichlorfon appeared to meet the requirement, having fast fading contact residues and remaining in the leaves as a stomach poison. A few campaigns were carried out against both bagworms and nettle caterpillars with good result and no noticeable resurgence.

\section{Mid 1960s to 1990}

There was good awareness among estate operatives and advisers, of the basic ecology of the pests. Serious bagworm (and other leaf-eating caterpillar) incidence became uncommon, and where there was some resurgence, it could usually be traced back to earlier disruptive applications. Selective methods were sometimes applied. The trunk injection (TI) technique was adapted for oil palm (Wood et al., 1974). In this, certain systemic organophosphate insecticides placed in a hole bored in the palm trunk can spread throughout the fronds and kill leaf-eaters. With no contact to natural enemies, it is highly selective. It was developed so as to cover large areas rapidly, allowing treatment of palms too tall for spraying, and on terrain unsuitable 
for tractor passage (Sarjit, 1986; Khoo et al., 1983; Chung, 1988).

Outbreaks in this period were infrequent and only occasionally serious. In a National survey of 1980-95 (Basri et al., 1988), 1406 oil palm estates in Malaysia as a whole, were asked to record any bagworm incidence (Table 1). Of 722 responses, over $90 \%$ were aware of bagworms. A total of 1317 surveyed properties were in Peninsula, of which 668 responded, with $88(13 \%)$ reporting some bagworm attack, virtually all $M$. plana and/or $P$. pendula. Treatments were selective (spray of trichlorfon or TI), applied to a total of 27591 ha (or $2.1 \%$ of the total area). It appeared that need for reapplication was not common. Basri et al. (1988) suggested that the non-responders could have been affected in similar proportion, but probably equally likely, non-affected estates would be much less inclined to respond. A single estate group carried out a similar survey over its 69 estates (63 955 ha) distributed on the west side of Peninsula, from 1986 to 2000 (Ho et al., 2011). Up to 1990, there were only two very small incidences, one in 1986 (P. pendula) and one in 1990 (M. plana).

In another National survey (Norman and Basri, 1992), over a 10-year period from 1981 to 1990, 941 estates were asked about nettle caterpillar infestation, of which various species had commonly occurred in the 50s-60s. Of the 662 responses, 66 reported some incidence of those pests over the 10year period. Control of these pests too was by TI or selective sprays. The conclusion reached was that nettle caterpillars did not pose a major threat in that period. This gives some confidence that in general, natural balance was becoming restored after the disruption by pesticides around 1960 .

Chung (1988) reports investigation of aerial spray and TI against M. plana. These large scale applications effectively terminated incidence, without further infestation in the long-term. This confirms that such selective methods could aid in restoring balance where resurgence might otherwise continue. Reports on incidence and new control measures were uncommon in that period. Generally, it was not easy to find suitable infestation for trials for further ecological studies and development (Wood, 1976a).

\section{0 to Present}

Occurrence. Bagworm (and nettle caterpillar) incidence and outbreak frequency began to increase again. The survey of Ho et al. (2011) (see above Mid 60s to 1990) which had shown little incidence before 1990, indicated that from then on, there was an increasing appearance of bagworms, reaching over $12 \%$ of the estate area (=7811 ha) by year 2000. Tey et al. (2003) reported that 20\%-30\% of Peninsula estates of a large plantation group had incidence, mainly of M. plana, of varying degrees of severity.

Norman and Basri (2007), circulated a survey throughout Malaysia about bagworm incidence between 2000 and 2005. This covered 3880 properties, and received 1709 responses, 1071 of them from Peninsula estates. These controlled about 1.9 million hectare (of $c 2.3$ million hectares in 2005). One hundred and seventy two (16\%) reported bagworm outbreaks, mainly of $M$. plana and/or P. pendula, with a few M. corbetti. Mazmira et al. (2015) reported that approximately 32475 ha estate and 5100 smallholder land in central Johor was infested by bagworms. Aerial application of (selective) Bt was programmed and in early 2012, 3320 ha smallholder area was covered. This was followed by 7500 ha in April 2013 and about 3000 ha in 2015. The cause of outbreak was ascribed to 'uncontrolled application of chemical insecticide' and removal of ground cover. The short-term results of the $\mathrm{Bt}$ applications were variable, but outbreaks progressively declined with no further applications. Various studies on aspects of bagworm biology and pest management strategies at the time easily found plenty of infested areas for such work.

Pesticides. Various possibilities have been tested in the intervening years. Two are added to the previously chosen selective ones for more common use if needed. One of them comprises materials derived from Bacillus thuringiensis, and the second, synthetic pyrethroid (SP) insectides, specifically cypermethrin and deltamethrin. In this period, there has been progressive increase in infestation in association with more applications.

TABLE 1. BAGWORM OCCURRENCE IN MALAYSIAN OIL PALM ESTATES, 1980-85, REPORTED IN A NATIONAL SURVEY*

\begin{tabular}{lcccrr}
\hline Region & $\begin{array}{c}\text { Estates } \\
\text { circulated }\end{array}$ & Responded & $\begin{array}{c}\text { Bagworm } \\
\text { reported }\end{array}$ & \multicolumn{2}{c}{ Hectares in 1985 (MPOB, 2017) } \\
\cline { 5 - 6 } & 1317 & 668 & 88 & 1292399 & Affected \\
\hline Peninsula & 78 & 45 & 9 & 161500 & 27591 \\
Sabah & 11 & 9 & 1 & 28500 & ca.1000 ha $^{* *}$ \\
Sarawak & & &
\end{tabular}

Source: *Basri et al. (1988).

**Tiong (1979). 
In the surveys (Norman and Basri, 2007) and other cited reports, the pesticides used generally are not named. Often, they mention a systemic organophosphate, which indicates TI, or 'spray' or 'spraying', which usually means of an SP. The implication of the increase in use of such applications and relationship to increased infestation is considered further below in Pesticides in Large Scale and Recent Use.

Worsening infestation. The problem was becoming very serious, with major infestations attracting an editorial (Anon, 2013). The cost of applying control measures was high, and still expensive crop losses were occurring. Management were advised to be aware of incidence and take appropriate steps on an on-going basis. Nonetheless, the problem evidently continued to get worse, as covered in a further editorial (Chung, 2018).

A recent survey questionnaire was circulated to 19 estates in the state of Perak (MPOB, unpublished data), with active bagworm infestations and receiving on-going control measures, either spray applications of cypermethrin, TI or a combination of both. Within the eight estates which were successful in keeping the bagworm count below 10/frond, $56 \%$ of the pesticides used were for TI, compared to $44 \%$ which were used for spraying. Among the 11 estates which failed to keep the bagworm population below threshold, most of the pesticides used $(67 \%)$ were for spraying, compared to $33 \%$ of the pesticides being for TI. This suggests that the high levels of infestation were somewhat related to the manner of pesticide applications and that in such circumstances, use of systemic pesticides by TI tends to favour biological stability.

\section{SABAH}

\section{Mahasena corbetti in the 1960s and 70s}

Oil palm estates were being established from about 1955, and by 1990, covered about 240000 ha. In 1965, a damaging outbreak occurred of Mahasena corbetti, a species of larger individuals than $P$. pendula or M. plana (Wood, 1968). The pests in these outbreaks were in DGM. Prior use of endrin sprays to young palms was suspected, but there were no detailed records. From experience in Peninsula, trichlorfon was recommended, and a spray plane brought over. This applied a commercial $80 \%$ trichlorfon soluble powder formulation at $0.9 \mathrm{~kg}$ $\mathrm{ha}^{-1}$ (a dosage somewhat below ideal preference due to lack of availability of the material locally). It brought down the very high numbers, but there was resurgence from a residual population. Lead arsenate and trichorfon were applied with ground spraying machinery. Effectiveness continued to be variable, and in late 1968, two areas of respectively 265 and 525 ha were treated aerially, this time at $1.8 \mathrm{~kg} \mathrm{ha}^{-1}$. The bagworm in the two areas were in slightly different phase, but due to the logistics of bringing the plane from over 1600 $\mathrm{km}$ away, applications had to be at the same time (Wood and Nesbitt, 1969). In the first, timing was to recent full emergence of all the young bagworms - kill was high, and the outbreak came to an end. In the other, with the compromise in timing (before hatch was fully complete), the bagworm subsequently resurged to damaging numbers, with some areas of marked defoliation. The position was complicated by a parallel rise in numbers of nettle caterpillars (Wood, 1968).

Most oil palm plantings in Sabah remained free of pest outbreak, again indicating that natural balance was generally good. To ensure continuing investigation close at hand, the Sabah Department of Agriculture joined with the Commonwealth Institute of Biological Control to set up a Sabah sub-station, to investigate further. Very few parasitoids had been observed in the early days of the outbreaks (Wood, 1971b), but later these had built up considerably. In contrast to M. plana and P. pendula, flies (Diptera) as well as Hymenoptera were recorded as common parasitoids (Sankaran, 1970).

Syed and Shah (1977), investigating M. corbetti populations, took a strong ecological approach towards minimising pesticide use, considering that a key factor was pesticide disruption of natural balance. They also found a significant effect on natural balance from intensive weed destruction, then a common local practice in young palm plantings. This, they attributed to destruction of feed sources (in the form of nectar from flowers) and shelter for the parasitoids and predators, which evidently reduced their number and hence, their controlling effect. Planting of nectar producing flowers to encourage effective natural enemy populations became widely encouraged.

Syed (1978) noted that after the outbreaks of 1965-66, incidence of $M$. corbetti continued for some time, but remained serious only in the same locality. Even so, it was present in noticeable numbers in other places and times (Syed and Shah, 1977). Chemical control appeared necessary at times, and lead arsenate was being used (Syed et al., 1973) which would ensure optimum selectivity. Regular monitoring helped to maintain awareness of risks (Syed and Speldewinde, 1974).

\section{Mid-70s Onward}

Parasitism level was clearly reduced by applications of insecticides (Syed and Shah, 1977), but in the mid 70s-80s, pest incidence declined, with no major outbreak reported In the same National 
surveys as those for Peninsula (Table 1), of 78 Sabah estates circulated, there were 45 responses, of which nine reported bagworm outbreaks (almost all M. corbetti), with about 8000 ha in total for the five years treated 'in some way', including around 4500 'sprayed'. The pesticides were not specified, but in the country as a whole, and in the state, there was concentration on using selective measures. For nettle caterpillars, for the period 1981 to 1990 (Norman and Basri, 1992), there were 52 responses from 90 estates circularised with the survey. Of these 16 had recorded nettle caterpillar occurrence, with only six at outbreak level, also showing that balance was restoring.

Hoong and Hoh (1992), from their observations, proposed that several factors had been involved in causing outbreaks. These included 'indiscriminate spraying' of disruptive insecticides (some speculatively so, in small areas), clean weeding, inefficient application, poor detection and logistics, and weather, particularly dry spells. They emphasised the importance of natural enemy control. Teh (1996) reviews the later approaches, based on awareness of the events of the late 1960s. Application of possibly disruptive insecticides was discontinued in favour of selective materials and maintaining the best conditions for natural enemy establishment and activity. There had been no outbreak level incidence from about 1975 to his writing date of 1996.

\section{SARAWAK}

\section{Early Plantings to Present}

Oil palms were more recently introduced to this state, remaining below 55000 ha up to 1990, reaching 1.5 million more recently (MPOB, 2017). An outbreak of over 500 ha had occurred in 1976 of $M$. corbetti and a nettle caterpillar. Tiong (1979) recognised the significance of natural balance, but had no information on any previous disruptive application in the particular case. An aerial spray was carried out with lead arsenate. A further outbreak occurred a few months later, and a similar treatment applied. The M. corbetti population then evidently declined. In various studies on spray survivors, a range of insect parasitoids and predators of these species emerged from collected bagworms, as well as fungal and virus infected individuals, and there was no resurgence.

In the National survey (Table 1), of 11 estates circulated there were six responses, only one with incidence. No treatments were made. For nettle caterpillars, 12 estates were circularised with the survey, with five responses of which four, totalling about 1035 ha, reported need of treatment of some kind. There are no literature reports of serious incidence in later years.

\section{PARALLEL DEVELOPMENTS IN SUMATRA}

\section{Pre 1950s to 60s}

Oil palm plantations were established from about 1911, and remained free of any serious caterpillar infestation until the late 1950s (Hutauruk and Situmorang, 1971). There was then a policy of applying DDT dust to palms, with escalating infestations of bagworms and nettle caterpillars. Total defoliation was common (Wood et al., 1977). By the end of the 60s, the connection was recognised, and there was a switch to trichlorfon dusting. Infestation declined where this was done, for example a trial was conducted comparing DDT and trichlorfon dusting in 5 ha plots, totalling 80 ha respectively with each chemical. One or two generations later, there was resurgence in the DDT plots but not in those dusted with trichlorfon, in which parasitoids were noticed clearly to be building up (Hutauruk and Situmorang, 1971).

\section{0s to 1990}

An FAO project operated from 1973 to 1976 (Wood, 1974; 1976b), and as it progressed, it was noted that infestations of $M$. plana (and nettle caterpillars) were becoming less regular and serious. Only one upsurge of $M$. corbetti was recorded, which was satisfactorily dealt with by a single application of trichlorfon. Aerial spray campaigns were carried out with selective materials, and TI was taken up (Wood et al., 1977; Djamin, 1988). Infestations continued to decline in the later 70s, and noticeable damage was no more than occasional (Djamin, 1988). The last treatment against bagworms before 1990 was in 1978.

\section{Post 1990}

Sumantri et al. (2011) noted that there had been no reports of leaf-eater attack through the 1980s, but some resurgence occurred in the 1990s. Outbreaks then became more regular, widespread, and damaging. This was associated with control attempts generally by applications of an SP, deltamethrin, often by fogging. Attacks were becoming more intensive into the 2000s. Much of the heavy damage involved nettle caterpillars, but bagworm resurgence was also common. Two incidents of M. plana on young palms were noted (Sumantri et al., 2011), both in places where the SP had been used. One of them, on 3-year old palms, followed a randomised Oryctes control trial, where one treatment (over $20 \%$ of the 40 ha trial area) had been sprayed with deltamethrin monthly for the first two years (Cahyasiwi et al., 2010). In south Sumatra, an attack by the bagworm Dapula (Clania) tertia developed from about 2004, on about 7-year old palms. Earlier treatment for leaf- 
eating cockchafers was the suspected cause. Various pesticides were being applied against the bagworm, including organophosphates, SP insecticides, and neonicotinoids, but the attack spread and became more severe. There was a switch to TI only and the outbreak cleared up by 2008. This is the only known record of a significant outbreak of that species on oil palm.

In Sumatra generally in recent years, in cases where SP insecticides are discontinued, serious infestations of both bagworms and nettle caterpillars have declined - aided by application of selective treatment if and when needed (Cahyasiwi and Wood, 2016). Where SP sprays are still applied, infestations commonly start and become more severe (Cahyasiwi, pers. comm., 2018).

\section{EVALUATION OF OCCURRENCE FROM 1990}

\section{Recognition of the Ecology}

Most authors covering the incidence and control of bagworms recognise the importance of ecological factors (e.g. Chung, 1988; 1998; Chung and Narendran, 1996; Ho and Teh, 1999; Hoong and Ho, 1992; Wood, 1968; 1971a). Wood (2002; 2013) has previously reviewed the topic.

A crucial point that has become increasingly evident in preparing the present review is that most plantings remain free of serious caterpillar upsurge. There is no indication that the basic environment and ecology of oil palm plantations is changing. Nonetheless, there is a clear trend to escape from natural control of pests at certain times and places, a trend that appears to be increasing. An investigation of possible reasons for that is opportune. Several authors cited above mention the need of providing the best agroenvironment for the natural enemies to establish and survive. This includes minimising conditions for the blowing of ground dust, such as from estate roads, onto the palms (Wood, 1968; Syed et al., 1973), and especially the need to encourage ground vegetation to provide food and shelter for natural enemies (Syed and Shah, 1977; Tiong, 1979; Ho and Teh, 1999; Norman et al., 2011).

\section{Pesticides in Outbreaks - Cause or Cure?}

The risk of disruption to natural balance by pesticides was specifically noted by many contributors, including Basri et al. (1988; 1990), Liau (1992), Norman et al. (2011), Teh (1996) and Hasber et al. (2015). Similar recognition with specific reference to natural enemy activity was accorded by several, including Basri et al. (1995), Desmier de Chenon et al. (1990), Norman and Othman (2016), Sankaran (1970), Syed and Shah (1977), Syed and Saleh (1993), and Tiong (1982).
The earlier history of incidence reviewed here clearly suggests that disruptive chemical applications is a main cause of outbreak. This makes it surprising, perhaps, that no authors appear to have suggested nor explored the possibility that pesticides are involved in causing the increased trend to outbreak in recent decades in Malaysia.

Selectivity is relative. Some further elaboration of the term 'selective' may help to clarify how pesticides can disrupt natural balance on one hand, and act to restore it on the other. In this context, selective pesticides are those that kill pests whilst sparing enough natural enemies to resume and continue natural control (Bartlett, 1964; Wood, 2015). The key point is that the application kills leaf-eaters (pests) more than enemies, thus tipping balance in favour of those natural enemies in the period of recovery. The specific characteristics that determine the potential of pesticides for selectivity are covered (see above - Protection Ecology Shown by These Experiences - Selective Treatments). Some of those characters are fixed. The spectrum of kill may be precise, with target pest groups being susceptible to a chemical, but their natural enemies not so. A purely stomach acting poison will only kill those that feed on it - leaf-eaters in this context. But there may be a range - a chemical may give a more thorough kill of pests than enemies in one circumstance, the reverse in another. Similarly, pesticides with fast fading contact residues may not always kill the pests in sufficient proportion, and so leave the balance favouring their resurgence.

Good kill as part of selectivity. There are important practical consequences in the sometimes graded selective effect. The key is to tip the balance in favour of the enemies. Natural enemies are essentially mobile and exploratory, whilst leaf-eating pests are more static. Therefore, for pesticides with selective potential on a range, it is likely that the enemies will be equally affected by application whether or not timing and coverage are adequate, whereas the kill of the static pests will depend on the thoroughness and timing of coverage. This means that once application is decided on, the better the kill of the pest, the higher the proportion of surviving natural enemies (Wood, 2002; Chung and Sim, 1993). This may well be a factor in the rather different recovery patterns after trichlorfon sprays between $M$. corbetti in Sabah on one hand, and M. plana and P. pendula in Peninsula on the other. There was clearly more success in restoring the balance with $M$. corbetti when there was a good kill. This aside from the different parasitoid groups (see below - Pesticides in Large Scale Recent Use - Trichlorfon).

Application methods and coverage. It follows that often, outbreaks have been worsened or even 
largely induced by poor coverage from pesticide application. The difficulties of getting good pesticide application in taller palms especially on uneven ground are well recognised (Wood, 1968; Khoo et al., 1983; Ho, 1988). Shoulder mounted motorised knapsacks can reach up to seven-year old palms, at most. Tractor drawn power sprayers may give coverage up to around 15-17 years old palms, but are only practicable on even terrain. Aerial application can be effective, but the high fixed cost for small areas, and the logistics of aeroplane operation continued to add difficulties (Basri et al., 1988). A compromise appeared to be fogging, but this gives very variable and generally uneven coverage, whilst the aerosol mist will effectively kill the free flying natural enemies (and also pollinating weevils). Serious incidence of leaf-eaters has been associated with this method, as in Sumatra ( $q v)$. TI gave a way to avoid these difficulties most of the time (see below - Pesticides in Large Scale Recent Use Trunk Injection).

Pests reappear in particular places. Such effects can play a part in determining which species appears, and where. In the balanced pest-free situation, both pests and their natural enemies are rare (Wood, 1973). That balance at very low numbers still fluctuates and the effect of a disruptive application will depend on the balanced state of particular potential pest species. Once one pest species has increased to outbreak levels, it will be present for a long time in much higher numbers than usual. With trend to DGM, it is the most likely to appear with any further disruption. That can then be seen as 'the species' of the area. No doubt environmental factors also play a role when they come into this association of particular species with particular locations and conditions (Chung, 1998).

Large scale testing and consistent safety in repeated applications. A further important practical aspect of the relative nature of selective applications is that pesticides of apparent selective potential need to be tested on a wide scale, and constantly monitored for upsets in the prevailing conditions (Wood, 1968; 1979; Wood and Chung, 1986; Chung, 1988). Replicated plot trials are probably inappropriate for these assessments, which require long-term observation over extensive areas.

\section{PESTICIDES IN LARGE SCALE RECENT USE}

The applications where significant use is reported in recent decades are TI, and for spraying, trichlorfon, products derived from Bacillus thuringiensis, and SP insecticides (e.g. cypermethrin, deltamethrin, etc.).
These are discussed separately in the following topics.

\section{Trunk Injection}

TI has been the treatment of choice since the mid-1970s. It has been used successfully without repercussion in campaigns ranging from a few palms to extensive areas in Peninsula (Khoo et al., 1983; Wood and Chung, 1986; Wood, 1987; Ho and Teh, 1999), and in Sabah (Teh, 1996).

Whilst chemical residues may remain in the leaves for some time, and occasionally have been shown to kill further pest generations, timing is often extremely important. Application is optimum when done immediately after full emergence of young caterpillars (Wood, 1976a; 1988). Chung and Sim (1993) clearly show that with reliable census, very good timing can be achieved and hence, good results are attained.

As the pesticides in TI have only stomach poison action, the method is reliably completely selective. There may be some mortality to parasitoids in developing caterpillars on the leaves (Basri et al., 1990; Hoong and Ho, 1992), but this would not be expected to differentially reduce the natural enemy population to a level that would disrupt the natural balance. No resurgences have been reported in these trials. Improvements in operational logistics of TI continued to be developed (Sarjit, 1986; Chung, 1988; Yap, 2000; 2005).

Pesticides are not broadcast, which makes it easy to protect field operators, but legislation relating to toxicology may come to affect the availability of suitable pesticides. Although this is beyond the scope of this review, it is noted that systemic organophosphates of lower mammalian toxicity are increasingly being used. These tend to be rather less effective than the earlier ones. This needs to be kept in mind in development programmes. TI is an ideal way to deal with bagworm and other leaf-eaters, with negligible environmental impact or toxic risk to the operator (provided that proper protective procedure is followed). The drilling of holes in palm trunk has not caused any significant damage (Wood, 1987), and there are no detectable pesticide residues in the edible products (Yap, 2005).

\section{Trichlorfon (= trichlorphon)}

This has been the standard for spraying operations since the first major outbreaks of bagworms in the early 1960s, by ground and aerial campaigns. It was employed for its potential selective qualities and it soon demonstrated good kill of M. plana and P. pendula (Conway and Wood, 1964; Wood, 1968; 1971a) and has continued to be used (Chung, 1988; Yap, 2005; Hasber et al., 2015). Chung (1998) observed that in this long usage, 
there had been no severe resurgences, but the cost per application had relatively increased, which Yap (2005) confirmed. Some difference in its selectivity in Sabah where M. corbetti had built up was noticed (see above - Sabah - M. corbetti in the 1960s and 70s). The chemical is particularly recommended as relatively safe for Hymenoptera parasitoids, whereas the larger $M$. corbetti, uniquely among these oil palm bagworms, harbours several tachinid flies among its common parasitoids (Wood and Norman, in preparation). Teh (1996) noted that parasitism by tachinids was lower in nettle caterpillars where trichlorfon was applied. Although no major flare ups were reported, the applications were discontinued and the infestation subsided. Khoo and $\mathrm{Ng}$ (1999) questioned the selective qualities of trichlorphon, and did bioassay tests which showed that the contact residues indeed faded quite fast. Trichlorfon remains an important selective chemical in oil palms, perhaps with some extra care where $M$. corbett $i$ is involved.

\section{Bacillus thuringiensis (Bt) Pesticides}

Toxins produced by Bt work entirely as stomach poisons and have long been known to be effective against leaf-eating caterpillars. Bt-based products were described by Wood (1979) as perfectly selective. Their potential in oil palm was tested by Ho (1988) and by Syed and Saleh (1993) who also advocated the need for large scale tests in various conditions before commercial use. Chung and Narendran (1996) showed its good potential against M. plana in a nursery trial. In exploratory field use, Bt products have often given good reduction in bagworm numbers (Hoong and Ho, 1992; Yap, 2005), but variable or ambiguous results have been noted (Teh, 1996; Hasber et al., 2015). Sometimes, there is relatively little controlling effect from the commercial products Thuricide and Dipel (Basri et al., 1988). Variation in effect, similarly has been found in Sumatra (Cahyasiwi and Wood, 2016).

Basri et al. (1994) recognised the value of $\mathrm{Bt}$ against M. plana. However, there was a wide variation among eight different products. They concluded that there was also a good prospect of finding a strain well or specifically adapted to bagworms. Basri et al. (1996) showed a marked difference in toxicity between $M$. plana and M. corbetti to particular strains of $\mathrm{Bt}$, although there was good kill compared with trichlorfon, at a high enough dosage. At the time though, the effective dosages were comparatively very expensive. Work on the biological mode of action and genetic chemistry continued (Siti Ramlah and Nor Muhammad, 1999), suggesting ways towards producing strains more specific for the bagworms. In the early 2000s, the Malaysian Palm Oil Board (MPOB) produced a strain known as Terakil-1, active against oil palm leaf-eaters to a much greater efficiency than the commercial products (Siti Ramlah et al., 2005). A formulation suitable for fogging, Bafog- 1 was also produced (Mohd Najib et al., 2013). Fogging in this case gave good control of $P$. pendula, contrary to the worsened adverse effects from poor cover with disruptive insecticides. A strain suitable for spraying (Ecobac-1) now gave good control during outbreak levels of M. plana and also on large scale by aerial application over about 290 ha (Noorhazwani et al., 2017). Clearly there is good promise of these more specific Bt formulations for completely selective control of bagworms and other oil palm leaf-eaters, and further development is to be encouraged.

\section{Synthetic Pyrethroids}

When the outbreaks caused by the then new disruptive organochlorine pesticides first affected the oil palm plantations in the 1950s and 60s, pyrethrum (derived directly from plants), which has fast fading residues, was considered a selective prospect (Conway and Wood, 1964). The development of the synthetic analogues (cypermethrin, deltamethrin, etc.) appeared to offer selective alternatives for oil palms. Some use is reported from about the mid-1980s. Wood (1988) noted that these formulations 'were finding a role' for both bagworms and nettle caterpillars. The residues were reputed to be fast fading, and Wood (1987) suggested that selectivity might be improved by using the lowest dosage effective in killing the pests. Chung (1988) found that results with six SP pesticides showed a marked reduction of M. plana, but less than complete (which was ascribed to inadequate coverage). In the same trial series, there was good kill of nettle caterpillars using machinery which provides better coverage. Norman and Basri (1992) reported that cypermethrin was in common use on estates, while Chung et al. (1994) included it as a 'common practice' application in oil palm plantations.

Some authors confirmed good kill, but sounded caution, recognising potential disruptive possibilities (e.g. Liau, 1992; Chung and Narendran, 1996). The latter authors found that in a single application, cypermethrin at $22.5 \mathrm{~g} \mathrm{ha}^{-1}$, it was the cheapest of a range of pesticides tested. Chung (1998) noted that in use at that rate for the past three or four years, no deleterious side effects had been seen. Teh (1996), in Sabah, recommended that SP insecticides could be used but only in small pockets of infestation, since they 'kill natural enemies'. Ho and Teh (1999) however, found that in a 775 ha block of oil palms of around 6-7-year old palms in Sabah, recurrent infestation by nettle caterpillars was not resolved by repeated application of an SP, but when these applications stopped, in favour of non-chemical approaches, the outbreaks terminated. Experience 
in Sumatra post 1990 also clearly associates leafeating caterpillar outbreak with SP application. Nevertheless, SP insecticides continued to be used, both in trials and large scale field practice (e.g. Yap, 2005; Hasber et al., 2015).

The likely risks from SP insecticides have become increasingly known in agriculture and horticulture in general. They have a higher biological activity and stability with longer residual effects than basic pyrethrum has (Tomlin, 2009). Cypermethrin, for example, can 'adversely affect IPM' in many crops (Anon, 1995). They are very effective for pests in closed spaces and domestic situations, but in agriculture, the broad spectrum residual contact action has been associated with killing of economically desirable insects, particularly adult parasitoids (Garcia, 2011). The first author of the present review acknowledges a change in his evidence, post 1990! Experience of pest outbreaks induced by these pesticides includes mites on tea in India, mites and other leaf-eaters in flowers in Kenya (Wood, 1997), and in an outdoor chrysanthemum project in Gambia (Wood and Lockwood, 2012).

\section{REASONS FOR APPLICATIONS}

The question naturally arises, if outbreak is predominantly induced, why are applications made in the first place?

\section{Perceptions and Preferences}

Various reasons exist in the perceptions of plantation operatives, particularly as a precaution because of expectation of imminent infestation. This might be from small incidence in the estate or neighbourhood, or some weather factor that, for some reason, has come to be associated with a build up. The cause may be defensive - if any damage, even minor, should arise, it could be judged better to have 'done something'.

On this topic, invasions suddenly to outbreak level are not likely. Bagworms spread only by caterpillars walking from palm to palm, or newly hatched larvae 'floating in the wind' (Rhainds et al., 2002). Even with flying stages (like nettle caterpillar moths), population density rapidly decreases exponentially with distance from an infested patch, so no significant numbers can generally be expected in the first generation of arrivals. They will only increase from that if conditions favour it. Furthermore, natural enemies will be there to build up, if left to do so.

If there are caterpillars in the palms (induced or otherwise, and however few), planters may like to see a quick kill, and dead ones on the ground. Immediate or short-term cost may be a factor, but this tends to compare one application against another, without considering the likelihood of longterm damage and resurgence.

\section{Treatments against Other Pests}

Disruptive pesticides might be applied against other pests. This may not disadvantage the target pest, but still incidentally could start a cycle of outbreak, control and reoutbreak of leaf-eating caterpillars. This is especially likely in young plantings.

Oryctes. In replants, the trunks of old felled palms can become prolific breeding sites, and emerging adults can then severely damage the young palms and set back the planting (Norman and Basri, 1995). A high proportion of estates with replanting can be affected, based on a survey in the 1990s (Norman and Basri, 1997), made worse by, inter alia, introduction of decaying material such as heaped empty fruit bunches (EFB) from the mill, as mulch. Further destruction of all the old trunks is often practiced (Norman and Basri, 1995; Ho and Teh, 1999), and damage is well contained by a reasonably dense ground vegetation cover, which lowers the egg-laying in the old trunks, and more importantly, greatly reduces the attack on the young palms (Wood, 1969). This is assumed to be because the beetles' searching flight is impeded by the vegetation. A field survey by Norman et al. (2005) confirmed the major effect of ground cover, showing that Oryctes grubs were absent from piles of trunk chips, provided that the cover crop was at least 50 cm deep.

Insecticides placed into the spear leaf base can protect palms (O'Connor, 1957). This was adapted for young oil palms with insecticides in granular form (Toh and Brown, 1978), and various pesticides can be effective (Chung et al., 1993). The topical (precise spot) placement leaves natural balance practically unaffected. Trials showed that spraying of various SP insecticides could similarly act against adult beetles. 'Prophylactic' spraying of these pesticides has become regular field practice of some planting organisations, and it is often followed by leaf-eater build up. The connection may not always be recognised, but sometimes there is specific evidence - e.g. in the plot trial on Oryctes control in Sumatra, with one of five treatments with regular blanket coverage of deltamethrin, the trial area became the focus of an outbreak of $M$. plana (see above - Parallel Developments in Sumatra Post 1990). In a 2005 survey, Norman and Basri (2007) circularised to 1709 estates, of which 363 reported Oryctes infestation in replantings. Most were using pesticides, the majority carbofuran granules, but 11 of the responding estates were spraying cypermethrin. 
Cahyasiwi and Wood (2013) found that a policy of early establishment of cover, supplemented by application of granules when monitoring indicates need, gives full economic control of Oryctes. If this is done correctly, there is little damage. Nozzles exist to direct spray only deep into spear bases, although this would require great care in use (Ho, 1996).

Leaf-eating cockchafers. Occasional attacks visible as 'shot-holes' on the leaves of young palms may be seen. Generally damage is not very serious, and they can be eliminated if necessary by a wide range of pesticides (Chung, 1998). This includes some BSLRC insecticides, although with attendant risks.

Grasshoppers. Valanga nigricornis is sometimes a problem. In the 1960s, application of dieldrin was effective, but was often followed by upsurge of caterpillars (Wood, 1976a). Chung (1998) has investigated alternatives, but more selective materials may still be needed.

Termites. Damage can be heavy on new plantings on peat soils (Chung, 1998). Effective control is reported by Lim and Silek (2001), applying fipronil. This has disruptive characteristics, and after blanket spraying, outbreaks of leaf eating-caterpillars are likely. Equally good control can be obtained by topical application to active 'runs', leaving natural balance practically unaffected (Cahyasiwi and Wood, 2016).

\section{Monitoring of Incidence}

Monitoring is important to confirm the need and timing of any actions, and refinements have been introduced since the early grid systems across fields. A detailed account is outside the scope of this review, and various systems are practiced. In general, stepped systems have been devised and seem most practicable now, going from permanent 'general observation' (by all who work in the field), to 'alert' (more detailed inspection for damage) and 'enumeration' (counting number and stage of the pests on the leaves, if there is sign of infestation). The main objectives continue to be to determine any need of application, and to assess results of that, or follow developments where there is concern but no immediate action (e.g. Wood, 1968; 1985; Syed and Speldewinde, 1974). A collateral value of census monitoring is that management can show that a situation is recognised and can justify whatever decision has been taken. The fear of infestation in the area, or 'on the next door estate', should not be a cause to apply pesticides as a 'precaution' setting up alert monitoring would be the step to take.

\section{CONCLUSION}

The infestations of leaf-eating caterpillars, bagworms in particular, around 1960, were shown clearly to have been caused by pesticides that killed their insect natural enemies. The way out of this disruption of the natural balance most of the time was simply to halt applications, or, in persistent cases, aid the renewal of balance by application of selective insecticides in 'integrated' control. The latter was a rather novel approach in agriculture at the time, and the stress on the background natural controls contributed to the development of the science that later was called 'Integrated Pest Management' (IPM). As the agroecosystem settled, incidence of these pests up to the 1990s was sporadic and generally sub-economic. Things could have developed differently, with investigations mainly directed toward efficiency of spray coverage on tall palms and over uneven terrain. This would be with the BSLRC chemicals being used at the time, or others chosen for maximum kill in further trialling, in order to eliminate outbreaks as they occurred. Then, the cyclic nature of outbreak, treatment, and recurrence, might have appeared 'normal', as is (or was) the case in various other crops.

There is indication that this cyclic reduction and resurgence of bagworms is the way things are going now, in some cases. Since about 1990, infestation has become more widespread and recurrent, with concomitant increase in pesticide application. On the other hand, large areas remain practically free of significant or even noticeable incidence. The basic ecology has not changed. There is broad recognition of the ecological background among many of those responsible for field operations, particularly in the estate sector. This is coupled with appreciation of the role of natural enemy activity and environmental factors involved. The concept of pesticide selectivity also is generally accepted. However, an element that is apparently missing is consideration of the possible role currently regularly-used pesticides might play. The history of the 1950-60s outbreaks, the subsequent quiescence, experiences in other regions and crops, all point to this being a subject for careful practical investigation.

Such an investigation would be simple to design. It would entail allocation of an area such as a big estate or group, or a whole locality, where infestations and applications are an on-going factor. It would further entail the withholding of any applications of any possibly disruptive pesticides - of the four types currently in regular use, specifically the SP insecticides. At present, interim outbreaks can be dealt with only by TI or Bacillus thuringiensis materials. Trichlorfon could be used if most convenient, but with some reservation where $M$. corbetti is involved. In organising such a programme, any 'occasional' disruptive applications 
would have to be ruled out completely. They are always disruptive, and cannot be combined or alternated with IPM procedures. Similarly, control of other pests would totally avoid broadcast applications of disruptive BSLRC pesticides. Such (IPM) programmes are available. This includes against Oryctes, by early attention to generating full ground vegetation cover, and where necessary, topical application into spear leaves only.

Monitoring census would be important, using action levels to assess application need, and success. Levels proposed for various pests and circumstances are covered in many of the cited articles. Although arbitrary, they are generally very conservative, around average 10-20 live caterpillars per sampled frond. Treatment should always await the thresholds to be reached before action, and then used to ensure optimum timing. It is just as important not to make application if thresholds are not reached as it is to apply when they do. Repeated treatments in the same pest generation, disruptive or selective, are unlikely to be useful - in fact apparent need of any would indicate some fault in procedures. Usually, a short period of light damage is more tolerable than a long period (or permanence) of cyclic applications of a disruptive pesticide.

Aside from the controlled comparison that we suggest, the current general recommendation in oil palm plantings is to restrict application only to TI and Bt. Many occasions have shown evidence that bagworm incidence will then decline. Here too, such an IPM approach cannot be combined with an occasional disruptive measure. TI remains the ideal treatment for selectivity, ease of use, and economy, but some of the most effective systemic organophosphates (in particular monocrotophos and methamidophos) come under increasing legislative scrutiny. Acephate may be considered safer and is commonly used, whilst the search for further alternatives deserves high priority. The local formulations of Bt give promise of overcoming the variability often found with these products. It is important to recognise that they are slow acting, allowing time for pests to eat and then succumb visibly. There can be risk that Bt materials are adulterated to give quick kill, to satisfy users who judge effectiveness by a quick fall of dead pests. One bioassay showed a very rapid kill by Bt-based pesticides (Cahyasiwi and Wood, 2016) giving suggestion of this happening in practice. Bioassay facilities in general are useful to confirm that particular pesticides work in the expected way. More alternatives for application with good selective qualities may be identified in on-going research programmes.

In summary, the knowledge and science exist to move and stay away from any cycle of outbreak, treatment and reoutbreak. Pests are living organisms that exist in an environment (the crop agroecosystem), and controlling their number therefore is an exercise in applied ecology. Practical investigation, locally and pan-industry, is key to understanding that ecology and working with its constraints, for best sustainability and economy in oil palm pest control.

\section{ACKNOWLEDGEMENT}

The authors thank the Director-General of MPOB for permission to publish this article. The first author wishes to thank Dr R H V Corley for helpful and constructive discussions. The second author also thanks Nur Robaatul Adhawiyah for her help in searching various articles for this review.

\section{REFERENCES}

Anon (1995). Cypermethrin - A synthetic pyrethroid. Pesticides News, 30: 20-21.

Anon (2013). Recent large outbreaks of leaf-eating caterpillar. The Planter, 89(1050): 643-644.

Bartlett, B R (1964). Integration of chemical and biological control. Biological Control of Insect Pests and Weeds (DeBach, $\mathrm{P}$ ed.). Reinhold Publishing Company, New York, USA. p. 489-511.

Basri, M W; Hassan, A H and Zulkefli, M (1988). Bagworms (Lepidoptera: Psychidae) of oil palm in Malaysia. PORIM Occasional Paper No. 23: 37 pp.

Basri, M W; Norman, K and Hamdan, A B (1990). Field studies on the effects of insecticides on the natural enemies of the bagworm, Metisa plana (Lepidoptera:Psychidae). Proc. of the 1989 PORIM International Palm Oil Development Conference: Module II - Agriculture Conference. PORIM, Bangi. p. 263-272.

Basri, M W; Norman, K and Hamdan, A B (1995). Natural enemies of the bagworm Metisa plana (Lepidoptera: Psychidae) and their impact on host population regulation. Crop Protection, 14(8): 637-645.

Basri, M W; Siti Ramlah, A A and Norman, K (1994). Status report on the use of Bacillus thuringiensis in the control of some of oil palm pests. Elaeis, 6(2): 82101.

Basri, M W; Siti Ramlah, A A; Ramle, M and Othman, A (1996). Biological efficacy of three commercial products of Bacillus thuringiensis for the control of bagworms, Metisa plana and Mahasena corbetti (Lepidoptera: Psychidae) of oil palm. Proc. of the 1996 PORIM International Palm Oil Congress Competitiveness for the $21^{\text {st }}$ Century (Ariffin, D; Basri, 
M W; Rajanaidu, N; Mohd Tayeb, D; Paranjothy, K; Cheah, S C; Chang, K C and Ravigadevi, S eds.). PORIM, Bangi. p. 369-378.

Cahyasiwi, L; Wood, B J; Indra Lubis, F and Caudwell, R (2010). The economics of Oryctes attack in oil palm replants. Proc. International Oil Palm Conference. 1-3 June 2010, Yogyakarta, Indonesia. 8 pp.

Cahyasiwi, L and Wood, B J (2013). Factors influencing the incidence of Oryctes rhinoceros and its control in oil palms in Indonesia. Proc. of the $5^{\text {th }}$ Indonesian Oil Palm Research Institute (IOPRI) - Malaysian Palm Oil Board (MPOB) International Seminar of Pests and Diseases. p. 28-43.

Cahyasiwi, L and Wood, B J (2016). Strategy of nettle caterpillar control and the potential presence of RPW (red palm weevil) in oil palm plantations in Sumatra. Proc. of the $6^{\text {th }}$ Indonesian Oil Palm Research Institute (IOPRI) - Malaysian Palm Oil Board (MPOB) International Seminar of Pests and Diseases. Medan, Sumatra, Indonesia. September 2016. 14 pp.

Chung, G F (1988). Spraying and trunk injection of oil palm for pest control. National Palm Oil/Oil Palm Conference - Current Developments. 11-15 October 1988. 44 pp.

Chung, G F (1998). Strategies and methods for the management of leaf-eating caterpillars of oil palm. The Planter, 74(871): 531-558.

Chung, G F (2018). Bagworm problems, another scourge of oil palm plantings (editorial). The Planter, 94(1109): 473-475.

Chung, G F and Narendran, R (1996). Insecticide screening for bagworm control. Proc. of the 1996 PORIM International Palm Oil Congress: Competitiveness for the $21^{\text {st }}$ Century. PORIM, Bangi. p. 484-491.

Chung, G F and Sim, S C (1993). Bagworm census and control - A case study. Proc. of the 1991 PORIM International Palm Oil Congress - Progress, Prospects $\mathcal{E}$ Challenges towards the 21 $1^{\text {st }}$ Century: Module I Agriculture Conference (Yusof, B; Jalani, B S; Chang, K C; Cheah, S C; Henson, I E; Norman, K; Paranjothy, K; Rajanaidu, N; Tayeb, D and Ariffin, D eds.). PORIM, Bangi. p. 433-442.

Chung, G F; Sim, S C and Tan, M W (1993). Chemical control of rhinoceros beetles in the nursery and immature oil palms. Proc. of the 1991 PORIM International Palm Oil Congress - Progress, Prospects $\mathcal{E}$ Challenges towards the $21^{\text {st }}$ Century: Module I - Agriculture Conference (Yusof, B; Jalaini, B S;
Chang, K C; Cheah, S C; Henson, I E; Norman, K; Paranjothy, K; Rajanaidu, N; Tayeb, D and Ariffin, D eds.). PORIM, Bangi. p. 380-390.

Chung, G F; Sim, S C; Pow, K W; Liau, S S; Ong, G L; Hashim, K; Ho, C T and Ganapathi, N (1994). Crop protection practices in oil palm plantations. Proc. of the International Planters Conference. 24-26 October 1994. p. 143-154.

Conway, G R and Wood, B J (1964). Pesticide chemicals - Help or hindrance in Malaysian agriculture? Malayan Nature J., 18(2E3): 111-119.

Corbett, G H (1927). Insect pests of the oil palm in Malaya. Malayan Agricultural J., 15(9-10): 338-342.

Corley, R H V and Tinker, P B (2016). The Oil Palm. $5^{\text {th }}$ Edition. Wiley Blackwell, Chichester. 639 pp.

Desmier De Chenon, R; Sipayung, A and Sudharto, P S (1990). The importance of natural enemies on leaf-eating caterpillars in oil palm plantations in Sumatra, Indonesia - Uses and possibilities. Proc. of the 1989 International Palm Oil Development Conference - Agriculture Conference (Jalani, B S; Zin, Z Z; Paranjothy, K; Ariffin, D; Rajanaidu, N; Cheah, S C; Mohd Basri, W; Henson, I E and Tayeb, D eds.). PORIM, Bangi. p. 245-262.

Djamin, A (1988). Crop protection and pest management of oil palm in Indonesia. Pesticide Management and Integrated Pest Management in South East Asia (Teng, P S and Heong, K L eds.). Consortium for International Crop Protection, Maryland, USA. p. 205-212.

Garcia, P (2011). Sublethal effects of pyrethroids on insect parasitoids: What we further need to know. Pesticides - Formulations, Effects, Fate (Margaritia, T ed.). p. 475-494.

Gater, B A R (1925). Insects on African oil palms. Malayan Agricultural J., 13(8): 250-256.

Hasber, S; Che Salmah, M R; Abu Hassan, A and Salman, A A (2015). Efficacy of insecticide and bioinsecticide ground sprays to control Metisa plana Walker (Lepidoptera: Psychidae) in oil palm plantations, Malaysia. Tropical Life Science Research, 26(2): 73-83.

Ho, C T (1988). Mechanized mistblowers for treatment of oil palm leaf pests. National Palm Oil/ Oil Palm Conference - Current Developments. 11-15 October 1998. 44 pp.

Ho, C T (1996).The Integrated Management of Oryctes rhinoceros (L) populations in the zero 
burning environment. Proc. of the 1996 PORIM International Palm Oil Congress: Module I - Agriculture Conference (Ariffin, D; Mohd Basri, W; Rajanaidu, N; Tayeb, D; Paranjothy, K; Cheah, S C; Chang, K C and Ravigadevi, $S$ eds.). PORIM, Bangi. p. 336-368.

Ho, C T and Teh, C L (1999). Integrated Pest Management in plantation crops in Malaysia. Challenges and realities. Proc. of the 1997 International Planters Conference - Plantation Management for the $21^{\text {st }}$ Century (Pushparajah, E ed.). Vol. 1. Incorporated Society of Planters, Kuala Lumpur. p. 125-149.

Ho, C T; Yusof, I and Khoo, K C (2011). Infestations by the bagworms Metisa plana and Pteroma pendula for the period 1986-2000 in major oil palm estates managed by Golden Hope Plantation Berhad in Peninsular Malaysia. J. Oil Palm Res. Vol. 23: 1040-1050.

Hoong, H W and Hoh, C K Y (1992). Major pests of oil palm and their occurrence in Sabah. The Planter, 68(793): 193-210.

Hutauruk, C and Situmorang, H S (1971). Some notes on the control of the bagworm Metisa plana Walk. in North Sumatra. Crop Protection in Malaysia (Wastie, R L and Wood, B J eds.). Incorporated Society of Planters, Kuala Lumpur. p. 166-172.

Khoo, K C; Ho, C T; Ng, K Y and Lim, T K (1983). Pesticide application technology in perennial crops in Malaysia. Pesticide Application Technology (Lim, GS and Ramasamy, S eds.). Malaysian Plant Protection Society (MAPPS), Kuala Lumpur. p. 42-85.

Khoo, K C and Ng, P L (1999). Is trichlorfon really suitable as an insecticide for use in oil palm pest management? $5^{\text {th }}$ International Conference on Plant Protection in the Tropics. 15-18 March 1999. Malaysian Plant Protection Society, Kuala Lumpur. p. 104-108.

Liau, S S (1992). The IPM experience in plantation crops. Proc. of the Conference Integrated Pest Management in the Asian Pacific Region. 23-27 September 1991, Kuala Lumpur, Malaysia. p. 51-63.

Lim, K H and Silek, B (2001). Termite infestation on oil palms planted on deep peat in Sarawak: Tradewinds experience. Proc. of the 2001 PIPOC International Palm Oil Congress - Cutting Edge Technologies for Sustained Competitiveness: Module 1 - Agriculture, Biotechnology and Sustainability Conference. MPOB, Bangi. p. 355-368.

MPOB (2017). Malaysian Oil Palm Statistics. 37th Edition. MPOB, Bangi. 205 pp.

Mariau, D (1976). Insect pests in West Africa. Oil Palm Research (Corley, R H V; Hardon, J J and Wood, B J eds.). Elsevier, Amsterdam. p. 369-383.
Mazmira, M M M; Najib, M A; Norhazwani, K; Norman, K and Siti Ramlah, A A (2015). Implementing an Integrated Pest Management (IPM) program for bagworm control in oil palm smallholdings in Johor. Proc. of the PIPOC 2015 International Palm Oil Congress - Oil Palm: Powering the World, Sustaining the Future: Module 1-Agriculture, Biotechnology and Sustainability Conference. MPOB, Bangi. p. 43-55.

Mohd Najib, A; Siti Ramlah, A A; Mohd Mazmira, M M and Basri, M W (2013). Efficacy of Bafog-1, formulated local Bacillus thuringiensis for controlling bagworm, Pteroma pendula (Lepidoptera: Psychidae). J. Oil Palm Res. Vol. 25(2): 228-234.

Noorhazwani, K; Siti Ramlah, A A; Mohamed Mazmira, M M; Mohd Najib, A; Che Ahmad Hafiz, C M and Norman, K (2017). Controlling Metisa plana Walker (Lepidoptera: Psychidae) outbreak using Bacillus thuringiensis at an oil palm plantation in Slim River Perak, Malaysia. J. Oil Palm Res. Vol. 29(1): 47-54.

Norman, K and Basri, M W (1992). A survey of current status and control of nettle caterpillars (Lepidoptera: Limacodidae) in Malaysia (19811990). PORIM Occasional Paper No. 27: 23 pp.

Norman, K and Basri, M W (1995). Control methods for rhinoceros beetle Oryctes rhinoceros (L) (Coleoptera: Scarabaeidae). PORIM Occasional Paper No. 35: 30 pp.

Norman, Kand Basri, M W (1997). Status of rhinoceros beetle, Oryctes rhinoceros (Coleoptera:Scarabaeidae) as a pest of young oil palm in Malaysia. The Planter, 73(850): 5-21.

Norman, K; Basri, M W and Ramle, M (2005). Environmental factors affecting the population density of Oryctes rhinoceros in a zero burn oil palm replant. J. Oil Palm Res. Vol. 17: 53-63.

Norman, K and Basri, M W (2007). Status of common oil palm insect pests in relation to technology adoption. The Planter, 83(975): 371-385.

Norman, K; Ramle, M; Mazmira, M; Mohd Najib, A and Siti Ramlah, A A (2011). Bagworms and Oryctes: Advances in pests control and management. Proc. of the $3^{\text {rd }}$ MPOB-IOPRI International Seminar: Integrated Oil Palm Pests and Diseases Management. MPOB, Bangi. p. 3-20.

Norman, K and Othman, A (2016). Diversity and activity of insect natural enemies of the bagworm (Lepidoptera: Psychidae) within an oil palm plantation in Perak, Malaysia. J. Oil Palm Res. Vol. 28(3): 296-307. 
Norman, K; Robinson, G S and Mohd Basri, W (1994). Common bagworm pests (Lepidoptera: Psychidae) of oil palm in Malaysia with notes on related South-east Asian species. Malayan Nature J., 48: 93-123.

O'Connor, B A (1957). Notes on the control of Oryctes rhinoceros L. by the use of insecticides. Agricultural J. Fiji, 28(1-2): 15-18.

Rhainds, M; Gries, G; Ho C T and Chew, P S (2002). Dispersal by bagworm larvae, Metisa plana: Effects of population density, larval sex and host plant attributes. Ecological Entomology, 27: 204-212.

Sankaran, T (1970). The oil palm bagworms of Sabah and the possibilities of their biological control. PANS, 16: 43-55.

Sarjit, S (1986). The use of electrical drills for more efficient trunk injection against bagworms in oil palms. The Planter, 62(719): 54-57.

Siti Ramlah, A A and Nor Muhammad, M (1999). Detection of Cry genes in Bacillus thuringiensis isolated from bagworms, Metisa plana. Proc. of the 1999 PORIM International Palm Oil Congress: Emerging Technologies and Opportunities in the Next Millennium: Module I-Agriculture Conference. MPOB, Bangi. p. 507-512.

Siti Ramlah, A A; Mohd Basri, M W; Mohd Najib, A and Mohamed Mazmira, M M (2005). Integrated Pest Management: Terakil-1, Cassia cobanensis and beneficial insects for controlling of bagworms infestation in Malaysia. Proc. of the PIPOC 2005 International Palm Oil Congress - Technologies Breakthroughs and Commercialization the Way Forward: Module 1 - Agriculture, Biotechnology and Sustainability Conference. MPOB, Bangi. p. 660-690.

Stern, V M; Smith, R F; Van Den Bosch, R and Hagen, K S (1959). The integrated control concept. Hilgardia, 29: 81-101.

Sumantri, A; Cahyasiwi, L; Wood, B J and Saleh, A (2011). Development of selective measures and strategies for nettle caterpillar and bagworm control on oil palms in Sumatra. Proc. of the PIPOC 2011 International Palm Oil Congress - Palm Oil: Fortifying and Energising the World: Module 1 - Agriculture, Biotechnology and Sustainability Conference. MPOB, Bangi. p. 612-624.

Syed, R A (1978). Bionomics of the three important species of bagworms on oil palm. Malaysian J. Agriculture, 51: 392-398.

Syed, R A and Saleh, A (1993). Management of insect pests of oil palm in PT PP London Sumatra
Indonesia plantations in Sumatera, Indonesia. Proc. of the 1991 PORIM International Palm Oil CongressProgress, Prospects and Challenges towards the 21 $1^{\text {st }}$ Century: Module I - Agriculture Conference (Yusof, B; Jalani, B S; Chang, K C; Cheah, S C; Henson, I E; Norman, K; Paranjothy, K; Rajanaidu, N; Tayeb, D and Ariffin, D eds.). PORIM, Bangi. p. 451-457.

Syed, R A and Shah, S (1977). Some important aspects of insect pest management in oil palm estates in Sabah, Malaysia. International Developments in Oil Palm (Earp, D A and Newall, W eds.). Incorporated Society of Planters, Kuala Lumpur. p. 577-590.

Syed, R A and Speldewinde, H V (1974). Pest detection and census on oil palms. The Planter, 50(581): 230-233.

Syed, R A; Shah, S and Liew, K T (1973). Occurrence and control of Mahasena corbetti (Tams) in oil palms in Sabah. Advances in Oil Palm Cultivation (Wastie, R L and Earp, D A eds.). Incorporated Society of Planters, Kuala Lumpur. p. 402-414.

Teh, C L (1996). Integrated Pest Management of leaf-eating caterpillars of oil palms in Sabah. The Planter, 72(844): 395-405.

Tey, C C; Liew, V K and Hern, S B (2003). Pests and diseases of oil palm in Malaysia and Indonesia - Guthrie's experience. Proc. of the PIPOC 2003 International Palm Oil Congress - Palm Oil, the PowerHouse for the Global Oil \& Fats Economy: Module I Agriculture Conference. MPOB, Bangi. p. 1046-1053.

Tiong, R H C (1979). Some predators and parasites of Mahasena corbetti (Tams) and Thosea asigna (Moore) in Sarawak. The Planter, 55(639): 279-289.

Tiong, R H C (1982). Oil palm pests in Sarawak and the use of natural enemies to control them. Proc. of the International Conference Plant Protection in the Tropics (Heong, K L; Lee, B S; Lim, T M; Teoh, C $\mathrm{H}$ and Yusof, I eds.). Malaysian Plant Protection Society (MAPPS), Kuala Lumpur. p. 363-372.

Toh, P Y and Brown, T P (1978). Evaluation of carbofuran as a chemical prophylactic control measure for Oryctes rhinoceros in young oil palms. The Planter, 54(622): 3-11.

Tomlin, C D S (2009). The Pesticide Manual. $15^{\text {th }}$ Edition. British Crop Protection Council, Alton Hampshire. 1457 pp.

Wood, B J (1963). Imported and indigenous natural enemies of citrus coccids and aphids in Cyprus, and an assessment of their potential value in integrated control programmes. Entomophaga, 8(1): 67-82. 
Wood, B J (1968). Pest of Oil Palms in Malaysia and their Control. Incorporated Society of Planters, Kuala Lumpur. $204 \mathrm{pp}$.

Wood, B J (1964). Severe outbreaks of caterpillars on oil palm estates in Malaya induced by the use of residual contact insecticides. Proc. of the $12^{\text {th }}$ International Congress of Entomology. p. 1.

Wood, B J (1969). Studies on the effect of ground vegetation on infestations of Oryctes rhinoceros (L) (Col., Dynastidae) in young oil palm replantings in Malaysia. Bulletin of Entomological Research, 59: 85-96.

Wood, B J (1971a). Development of integrated control programmes for pests of tropical perennial crops in Malaysia. Biological Control (Huffaker, C B ed.). Plenum Press, New York, USA. p. 422-457.

Wood, B J (1971b). The importance of ecological studies to pest control in Malaysian plantations. Proc. of the Conference on Crop Protection in Malaysia (Wastie, R L and Wood, B J eds.). Incorporated Society of Planters, Kuala Lumpur. p. 187-196.

Wood, B J (1973). Integrated control: Critical assessment of case histories in developing economies. Insects: Studies in Population Management (Geier, P W; Clark, L R; Anderson, D J and Nix, H A eds.). Memoirs 1, Ecological Society of Australia, Canberra. p. 196-220.

Wood, B J (1974). Pests of Oil Palm, Rubber and Cocoa in North Sumatra. Review of Estate Situations, Recommendations and Research Requirements. Project - Strengthening Research on Rubber and Oil Palm in North Sumatra, Working Paper No. 31. UNDP/FAO, Rome (mimeo). p. i-v,1-131.

Wood, B J (1976a). Insect pests in South East Asia. Oil Palm Research (Corley, R H V; Hardon, J J and Wood, B J eds.). Elsevier, Amsterdam. p. 347-367.

Wood, B J (1976b). Pests of Oil Palm, Rubber and Cocoa in North Sumatra. Review of Estate Situations, Recommendations and Research Requirements. Project - Strengthening Research on Rubber and Oil Palm in North Sumatra, Working Paper 45. UNDP/FAO, Rome (mimeo). p. i-iv,1-43.

Wood, B J (1979). Progress in the development of integrated pest control programmes in Malaysian agriculture. Strategies in plant protection. Proc. of the Plant Protection Seminar (Lim, T K; Lim, G S; Abdul, G I; Varghese, G; Singh, G and Teoh, C H eds.). Malaysian Plant Protection Society, Kuala Lumpur. p. 176-216.

Wood, B J (1985). Implementation of Integrated Pest Management in plantation crops. Proc. of the Seminar on Integrated Pest Management in Malaysia (Lee, B S; Loke, W H and Heong, K L eds.). Malaysian Plant Protection Society, Kuala Lumpur. p. 295-309.

Wood, B J (1987). Economic aspects and chemical control. Slug and Nettle Caterpillars - The Biology, Taxonomy and Control of the Limacodidae of Economic Importance on Palms in South-east Asia (Cock, M J W; Godfray, H C J and Holloway, J D eds.). CAB International, Wallingford, United Kingdom. p. 223-235.

Wood, B J (1988). Overview of IPM infrastructure and implementation in estate crops in Malaysia. Pesticide Management and Integrated Pest Management in South East Asia (Teng, P S and Heong, K L eds.). Consortium for International Crop Protection, Maryland, USA. p. 31-41.

Wood, B J (1997). The lessons for IPM from indiscriminate spraying. Tropical Agriculture Association Newsletter, 17(2): 10-12.

Wood, B J (2002). Pest control in Malaysia's perennial crops: A half century perspective tracking the pathway to integrated pest management. Integrated Pest Management Reviews, 7: 173-190.

Wood, B J (2013). Ecology - The crucial thread in crop protection developments past, present and future in South East Asian oil palms. Proc. of the $5^{\text {th }} M P O B-$ IOPRI International Seminar: Sustainable Management of Pests and Diseases in Oil Palm - The Way Forward. MPOB, Bangi. p. 230-253.

Wood, B J (2015). Oil palm insect pests - Field control by field investigation. The Planter, 91(1069): 245-256.

Wood, B J and Nesbit, D P (1969). Caterpillar outbreaks on oil palms in Eastern Sabah. The Planter, 45(518): 285-299.

Wood, B J and Chung, G F (1986). Suatu cara kawalan perosak yang tertahan di Timur Jauh (Sustainable protection methods in plantation agriculture in the Far East). Prosiding Temu Ilmiah Entomologi Perkebunan Indonesia 1986. 22-24 April 1986, Medan, Indonesia. $26 \mathrm{pp}$.

Wood, B J; Liau, S S and Knecht, J C H (1974). Trunk injection of systemic insecticides against the bagworm Metisa plana (Lepidoptera, Psychidae) on oil palm. Oléagineux, 29: 499-505.

Wood, B J; Hutauruk, C and Liau, S S (1977). Studies on the chemical and integrated control of nettle caterpillars. International Developments in Oil Palm (Earp, D A and Newall, W eds.). Incorporated Society of Planters, Kuala Lumpur. p. 591-616. 
Wood, B J and Lockwood, R (2012). An aphid infestation in an outdoor Chrysanthemum scheme in the Gambia - A cautionary tale. Agriculture for Development, 15: 20-23.

Yap, T H (2000). The intelligent management of Lepidoptera leaf eaters in mature oil palm by trunk injection (A review of principles). The Planter, 76(887): 99-107.

Yap, T H (2005). A review on the management of Lepidoptera leaf-eaters in oil palm: Practical implementation of Integrated Pest Management strategies. The Planter, 81(954): 569-586.
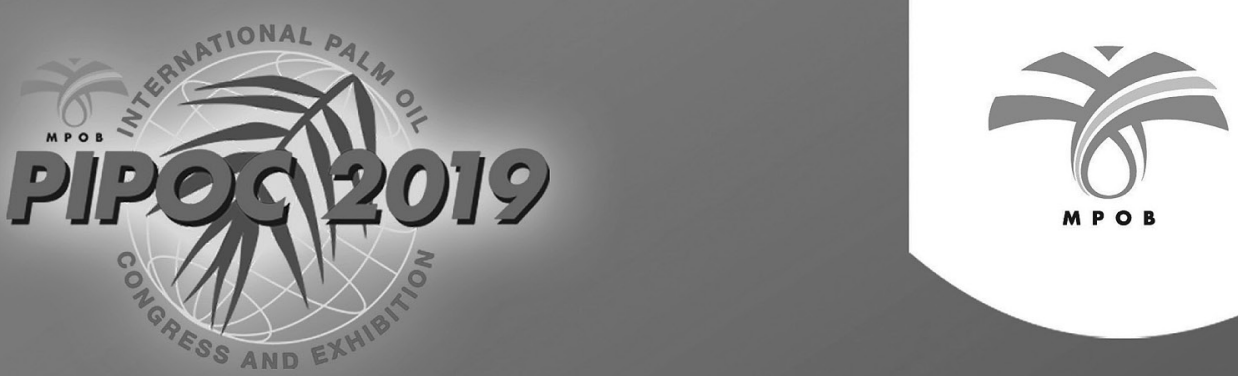

\section{MPOB INIERNATIONAL PALM OIL CONGRESS AND EXHIBITON ( PIPOC) 2019}

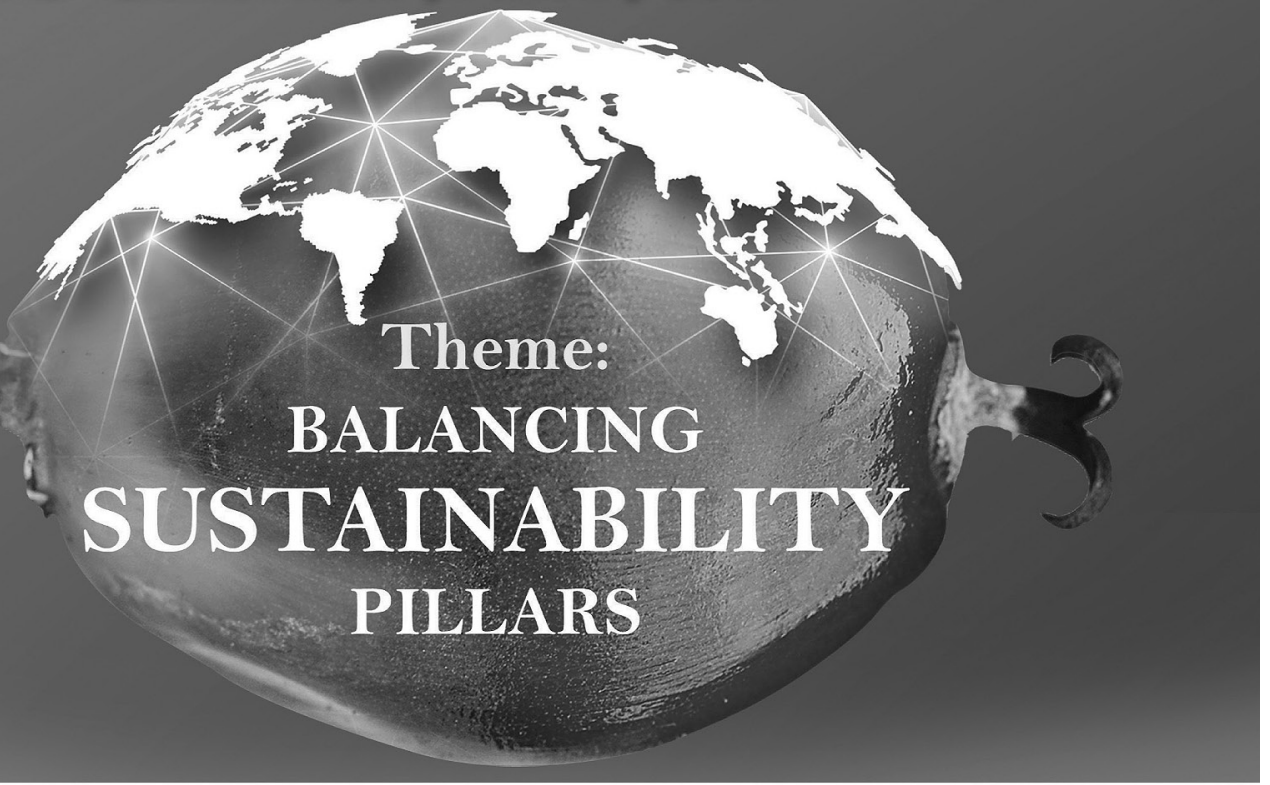

\section{9-21 Kuala Lumpur Convention Centre. NOVEMBER 2019 Kuala Lumpur, Malaysia}

\section{Join this prestigious event of 2019 ! \\ Organised by: \\ Connect with us at}

Malaysian Palm Oil Board (MPOB)

6. Persiaran Institusi, Bandar Baru Bangi. 43000 Kajang, Selangor, Malaysia

www.mpob.govmy
@ pipoc@mpob.gov.my

pipoc.mpob.gov.my

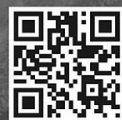

